\title{
Quantitation of Serum Lipids and Mucoprotein in Leprosy
}

\author{
AKIRA MAYAMA \\ (Research Institute for Tuberculosis and Leprosy, Tohoku Univerity, Sendai, Japan) \\ TARO SATO and SHIRO MAJIMA \\ (National Leprosarium, Tohoku Shinsei-en, Miyagi Prefecture, Japan)
}

The contents of total cholesterol, triglycerides, beta lipoprotein, total lipoprotein and mucoprotein in serum samples from 71 unfed patients with leprosy (6 tuberculoid, 40 lepromatous without reactional phases and 25 lepromatous with erythema nodosum leprosum), aged between 28 and 66 years were quantitatively assayed. They were free from atherosclerosis, heart diseases, diabetes mellitus, rheumatoid fever and/or syphilis. The concentration of total cholesterol was determined by Zak-Henly's procedure. Quantitative determination of triglycerides was carried out by Fletcher's technique. Beta and total lipoproteins were measured by the immunological precipitation method and cellogel electrophoresis. The serum mucoprotein content was determined by the method of Weimer and Moshins.

The mean value of total cholesterol was $154 \mathrm{mg}$ per $100 \mathrm{ml}$ in tuberculoid, $163 \mathrm{mg}$ per $100 \mathrm{ml}$ in lepromatous and $210 \mathrm{mg}$ per $100 \mathrm{ml}$ in ENL. The average serum triglyceride concentration was $90 \mathrm{mg}$ in tuberculoid, $94 \mathrm{mg}$ in lepromatous and $90 \mathrm{mg}$ per $100 \mathrm{ml}$ in ENL respectively. Namely, they were within normal value limits. In lepromatous leprosy with ENL, a remarkable increase in beta lipoprotein levels with an average of $470 \mathrm{mg}$ per $100 \mathrm{ml}$, and in total lipoprotein levels with an average of $870 \mathrm{mg}$ per $100 \mathrm{ml}$, were observed.

These values were markedly higher as compared with those of tuberculoid leprosy and lepromatous leprosy without ENL. As a result, it was found that hyperlipemia without hypertriglyceridemia occurred only in lepromatous leprosy suffering from ENL. Furthermore, the level of mucoprotein has shown a considerable increase in ENL cases. Namely, the mean value was $8.8 \mathrm{mg}$ per $100 \mathrm{ml}$ in tuberculoid, $10 \mathrm{mg}$ per $100 \mathrm{ml}$ in lepromatous and $14 \mathrm{mg}$ per $100 \mathrm{ml}$ in ENL respectively. In general, repeated examination revealed a gradual decline from the elevated levels of total cholesterol, beta and total lipoprotein, and mucoprotein at the recovery stage in the cases of ENL. 


\title{
らい患者血清の脂質とムコ蛋白
}

\author{
真山旭 \\ （東北大学抗酸菌病研究所） \\ 佐 藤太郎馬嶋四郎 \\ （東北新生園）
}

（受付1971年 5 月 26 日）

らい患者の血中脂質については，古くかららい研究者 や臨床家の検査対象となされてきたが，脂質測定法がか なり複雑で測定操作にも久点があり，また，長時間を要す る難点があった。しかし，試薬の品質や測定手技による 測定值の変動の困難をこえて, cholesterol 12388)9911)やリ ン脂質について主としてらいでは行なわれていた。最近 では各種の血中脂質の重要性からこれらの測定法に改良 が加えられ，きわめて短時間内に正確性のある測定値を 求めることが可能となってきたので, 改めてらい血清の 脂質について検討を加えることとした。なお，らい性結 節性紅斑時における CRP やリウマトイド因子について も問題となっているので，急性期反応物質の一つとして の血清ムコ蛋白についても調査してみた。

\section{測定方法}

\section{1）被検血清}

動脈硬化症, 心疾患, 糖尿病, リウマチ, 梅毒などの 臨床所見のある者は除き，一部は東北大抗研の外来者も 含め, 普通の日常生活を営んでいる東北新生園入所者を 対象とした。採血は朝食前の空腹時に行ない， $5 \mathrm{ml}$ 静 脈血を採取して血清を分離した。類結核型（T型）6， 採血時にらい反応相を認めないらい腫型（L型） $40 ， ら$ 、性結節紅斑を示すらい腫型（ENL）25, 計71例（28〜 66歳，大半が40，50代）である。なお，ENL 症例はそ のほとんどが入室加療中のものであり，ENL 皮疹出現 $3 \sim 6$ 日以内に採血したものを供試した。

2) 総 cholesterol 值

Zak-Henly 法により $\mathrm{mg} / \mathrm{dl}$ 值を測定した。

3）中性脂質值

和光純薬の triglyceride-test の acetylaceton 法によ り $\mathrm{mg} / \mathrm{dl}$ 值を計測した。

\section{4） $\beta$ リポ蛋白值}

Hyland 社の $\beta$-L test により免疫沈降法により沈降 層の高さを測定し，これを石戸谷ら5の方法にしたがっ て相関係数 $0.96 て ゙$, Iatron 社の沈降值に補正して同社の 換算表から $\mathrm{mg} / \mathrm{dl}$ を求めた。

5）総リポ蛋白值

Chemetron 社の cellogel 膜を使用し, 石戸谷ら ${ }^{6)}$ の 方法によってきわめて鮮明な血清りポ蛋白分画像の電気 泳動染色標本を作成し， 4 の $\beta$ リポ蛋白值 $(\mathrm{mg} / \mathrm{dl})$ を, $\beta$ と pre- $\beta$ リポ蛋白分画の百分率の加算值で除した值 を総りポ蛋白值 $(\mathrm{mg} / \mathrm{dl})$ とした。

6) ムコ蛋白値

orcinol による多糖類值測定を行なう Weimer-Moshin 法によって $\mathrm{mg} / \mathrm{dl}$ を求めた。

7) 血漿 fibrinogen 量

Quick 法により tyrosine 量を測定して fibrinogen 量 $(\mathrm{mg} / \mathrm{dl})$ に換算した。

\section{測 定 成績}

1) 総 cholesterol

T型 5，L型37，ENL 16 „計58例で検查したところ， 第 1 図のような成續であった。T型ではすべて $180 \mathrm{mg} /$ $\mathrm{dl}$ 以下であったが，L型では $200 \mathrm{mg} / \mathrm{dl}$ 以上のものが 5 例（45 62歳）に認妨れた。しかし，これらの平均值 はともにほぼ正常值を示した。一方，ENL を有するL 型では最低值が $140 \mathrm{mg} / \mathrm{dl}$, 最高值が $294 \mathrm{mg} / \mathrm{dl}$ であり, 大 半の症例で年齢にかかわりなく $200 \mathrm{mg} / \mathrm{dl}$ をこえており， したがって，その平均值も $210 \mathrm{mg} / \mathrm{dl}$ と高濃度を呈した のは注目に值しょう。

2）中性脂質値

T型 4，L型20，ENL 12，計 36 例で検討した成績を 

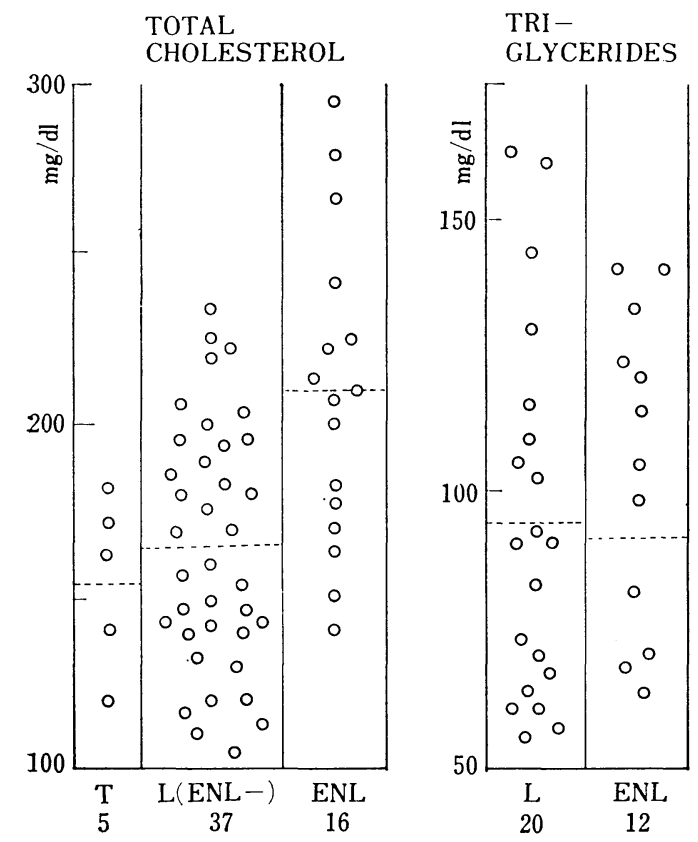

Fig. 1 Distribution of total cholesterol and triglycerides in serum of leprosy patients. $\mathrm{T}$ : tuberculoid leprosy, L: lepromatous leprosy without ENL, ENL: lepromatous leprosy with erythema nodosum leprosum. The dotted line represents the mean value.

第1 図に示した（ $\mathrm{T}$ 型は略，以下同様)。 $\mathrm{T}$ 型は 68〜 $112 \mathrm{mg} / \mathrm{dl}$ の範囲内にあって平均も $90 \mathrm{mg} / \mathrm{dl}$ となり， L 型は $70 \mathrm{mg} / \mathrm{dl}$ 以下の数值にとどまったものが 7 例あり, $100 \mathrm{mg} / \mathrm{dl}$ 以上が 8 例で最高值は $164 \mathrm{mg} / \mathrm{dl}$ であったが, その平均值は $94 \mathrm{mg} / \mathrm{dl}$ とT型に比しても大差がなかっ た。ENL 群についてみても，100mg/dl をこえた例が 大半を占めたが $140 \mathrm{mg} / \mathrm{dl}$ 以下で，平均も $90 \mathrm{mg} / \mathrm{dl}$ とな り中性脂質值では病型, 反応相による变化はないものと 思われた。

3） $\beta$ リポ蛋白

T型 5，L型37のほか，ENL 25，計67例で測定する ことができた。Hyland 社の抗血清による沈降值を Iatron 社のそれに転換して計測したところ， T型では平 均 $200 \mathrm{mg} / \mathrm{dl}$ で健康者とほぼ同值であったが，L型では $250 \mathrm{mg} / \mathrm{dl}$ をこえるものがかなりあり, 平均值も $310 \mathrm{mg} /$ dl を示した。とくに ENL 皮疹が発生してから数日以 内に採血しえた症例では, そのすべてが $300 \mathrm{mg} / \mathrm{dl}$ 以上 の高值を呈しており，最高は $745 \mathrm{mg} / \mathrm{dl}$ を示したためそ の平均も， $470 \mathrm{mg} / \mathrm{dl}$ となり著しい高值であった（第 2
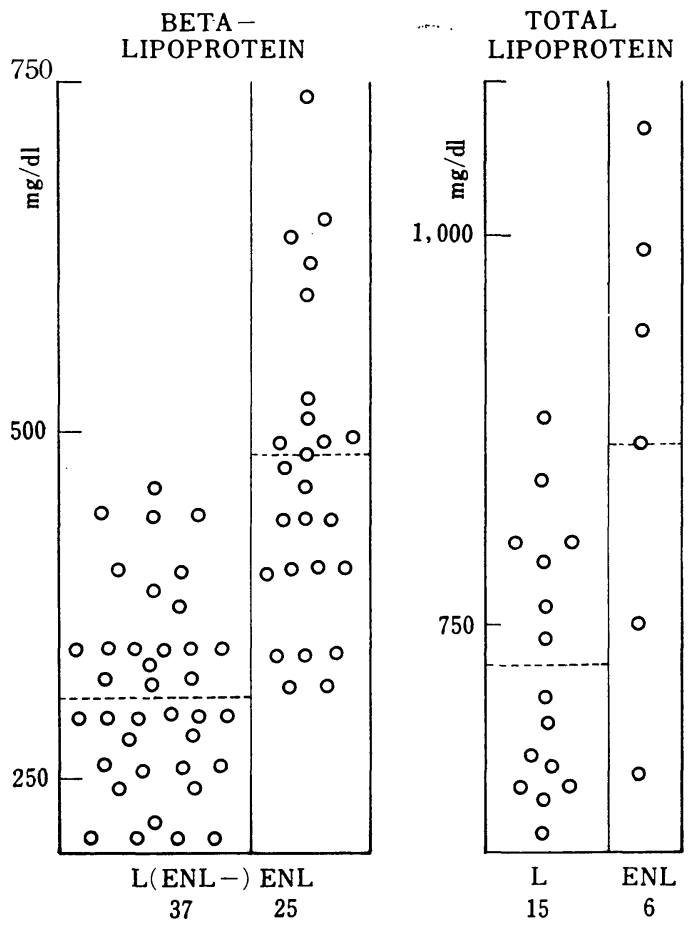

Fig. 2 Distribution of beta lipoprotein and total lipoprotein in serum of leprosy patients. Abbreviations: See Fig. 1.

図)。

4) 総リポ蛋白

T型 3，L型15，ENL 6，計24例で計測したにすぎな いが，T型では平均 $430 \mathrm{mg} / \mathrm{dl}$ であったのに対し， L型 ではすべて $600 \mathrm{mg} / \mathrm{dl}$ 以上を示しており, 平均も $720 \mathrm{mg} /$ $\mathrm{dl}$ と高值を呈した。とくに, ENL 症例では最高が $1078 \mathrm{mg} / \mathrm{dl}$ と著明な上昇值を示した例もあって，平均值 は $870 \mathrm{mg} / \mathrm{dl}$ となり反応相中の血中総りポ蛋白が異常に 増加することを認めた(第 2 図)。

5）么コ蛋白

$\mathrm{T}$ 型 4, L 型32, ENL 10, 計46例で定量したところ, $\mathrm{T}$ 型では7 $10.8 \mathrm{mg} / \mathrm{dl}$ の範囲内にあり平均値は $8.8 \mathrm{mg} /$ $\mathrm{dl}$ であった。一方， L型では $10 \mathrm{mg} / \mathrm{dl}$ を境として約半 数ずつ $7 \sim 14.8 \mathrm{mg} / \mathrm{dl}$ の範囲内に分布したが，その平均 はちょうど $10 \mathrm{mg} / \mathrm{dl}$ となり T型のそれと格別の差は認め られなかった。しかし， ENL では最低值が $9.4 \mathrm{mg} / \mathrm{dl}$ で あり $15 \mathrm{mg} / \mathrm{dl}$ をこえるものが 4 例をしめたためと，最高 值で $20.7 \mathrm{mg} / \mathrm{dl}$ と分布がかなり高值に偏しており, 平均 值も $14 \mathrm{mg} / \mathrm{dl}$ と著しく上昇していることがわかった（図 略)。 
6) 血漿 fibrinogen

T型 3，L型 11，ENL 8 例で法に従い蓚酸ナトリウ ム液による血漿分離を行ない測定したところ，T型では $200 \sim 245 \mathrm{mg} / \mathrm{dl}, \mathrm{L}$ 型で160 350mg/dl の範用を占め, 平 均值はそれぞれ $220,280 \mathrm{mg} / \mathrm{dl}$ であったのに, ENL では すべて $250 \mathrm{mg} / \mathrm{dl}$ 以上を示し, 最高 $560 \mathrm{mg} / \mathrm{dl}$ でその平均 も $430 \mathrm{mg} / \mathrm{dl}$ と異常に増加していることを認めた(図略)。

\section{まとめと考え}

血清の cholesterol は食事（外因性）に由来するも のと肝で生産される内因性のものとがあり，遊離型と ester 型の別があってその合算したものが総 cholesterol であることはいうまでもない。らい血清中の総 cholestrol については, 従来の報告例で Ross 以外はL型 で低值を示すとされていたが13318)9111)，これらの報告さ れた時代やその国々の栄養事情は現在とは対比不可能な ほどの差異があり，今回の調査ではほとんどが 40,50 代 であったためか, 性別による平均值の差はなく, T, L 両型ともほぼ正常值であったが，ENL の場合には 200 $\mathrm{mg} / \mathrm{dl}$ をこえる例が多く, その平均值も上昇しているこ とがわかった。また，血中の中性脂肪のほとんどを占 める triglycerides には, 食䬣脂肪からとりこまれた chylomicron（空腹時にはほとんど存在しない）と，肝 で合成された triglycerides の 2 種があるが，血中の mono-, di-glycerides が少量（約 $2 \%$ ）でしかもすぐ代 謝されてしまうため, triglycerides そのものが中性脂肪 として呼称されていることが多い。らいの場合には病 型, 反応相の別なくこの平均值はいずれもほぼ $90 \mathrm{mg} / \mathrm{dl}$ を示しており相互間の差異はなかった。

ところで血中総脂質は, cholesterol, triglycerides の ほかリン脂質, 遊離脂肪酸や少量の糖脂質からなるが, 血清蛋白質と結合してリポ蛋白として水溶性となり血中 を流れる。この場合に albumin と結合する遊離脂肪酸 は別として, 他は $\alpha, \beta$ globulin と結合して $\alpha, \beta$ リポ 蛋白として存在している。Frederickson')によると， $\beta$ リポ蛋白(低比重リポ蛋白) 中には, cholesterol $47 \%$, リン脂質 $23 \%$, triglycerides $9 \%$, 蛋白質 $21 \%$ を含み, $\alpha$ と $\beta$ lipoprotein の中間の易動度を占める pre- $\beta$ リポ 蛋白 (超低比重リポ蛋白) では triglycerides $52 \%$, cholesterol $22 \%$ ，リン脂質 $18 \%$ ，蛋白質 $7 \%$ を含むという。 免疫沈降法による の合算值として示されるか， cholesterol やリン脂質を 多量に含むこのßリポ蛋白值をらい血清で計測した結
果では，L型とくに ENL 症例で著しく増加しているこ とを認めた。したがって，血清総リポ蛋白值も L 型では T型より高值を示し，とくに ENL では異常に上昇して いることを確認できた。真山7)(1963)はさきに肝や皮下 脂肪で生産されるリポ蛋白分解酵素の活性值が， L型と 境界群のらいで著しく低下していることを報告したが， 今回の成績はこれと相関するものと思われる。らい反応 相とくに ENL 時には肝, 腎の障害が必発であり, 血清 $の$ transaminase ${ }^{10)}$, cholinesterase ${ }^{7)}(1965)$, lipoprotein lipase ${ }^{7)}$ (1965) などの測定や，肝生検標本の各種酵素 活性測定 ${ }^{2}$ によって, 肝の障害度をある程度推定しうる ことも可能であることがいわれているのは臨床的に重要 であろう。

らい反応相における血清中のC反応性蛋白質 (CRP) については既報したが7（1967)，簡便な測定の割にはら いの臨床においてかなりの意義を持っており有効性が 高いが，この病的蛋白の出現には血清中のムコ蛋白の増 加が重要な役割をなしている。また，らい血清とくに ENL の場合に人の $\gamma$ globulin に対する自己抗体とし てのリウマトイド因子 (RF) が高率に出現することも 前報したが7) (1968)，膠原性疾患や高度の肝病変時に RA-test の陽性率が上昇することから，血中のムコ蛋白 との関連も考慮されている。血清ムコ蛋白は hexosamine 含有 $4 \%$ 以上の糖蛋白を意味するが, orcine 試 薬によるらい血清の測定では，ENL 発生直後の症例で はかなり特異的に上昇していることが証明できた。

以上の成績より，らい患者中のL型とくに ENL を合 併している症例では, 高中性脂肪血症をともなわない高 cholesterol 血症を特徵とする高脂血症のあることが判 明したが，それは $\beta$ リポ蛋白増加を主力とする総リポ 蛋白の高值から成立することも証しえた。なお, 高脂血 症の場合に血液の凝固性が増進することが問題となって きているので, Cuick 法による化学的測定法により血液 凝固因子中の第一因子である fibrinogen 量を検查した ところ，T型で $220 \mathrm{mg} / \mathrm{dl}, \mathrm{L}$ 型でも $280 \mathrm{mg} / \mathrm{dl}$ とほぼ健康 者と同值であったのに, ENL では $430 \mathrm{mg} / \mathrm{dl}$ と著しく上 昇值を示していたのも強調すべき所見と思われた。

\section{ま と め}

1）動脈硬化症, 心疾患, 糖尿病, リウマチ, 梅毒な どの臨床所見のない類結核型（ $\mathrm{T}$ 型） 6 ，らい腫型（L 型） 40, らい性結節性紅斑を有するL型 (ENL) 25, 計 71例（大半が40, 50代）の空腹時の血清で，脂質量とム 
コ蛋白量を測定した。

2) 総 cholesterol の平均値は T型 154, L 型1 63, ENL $211 \mathrm{mg} / \mathrm{dl}$ であり, ENL で高 cholesterol 血症を 示した。

3) triglycerides 值の平均は $\mathrm{T}$ 型90, L 型94, ENL $90 \mathrm{mg} / \mathrm{dl}$ で, 病型や反応相の有無にかかわりなくほぼ健 康者と同值であった。

4) $\beta$ リポ蛋白の平均值は T型200, L 型310, ENL $470 \mathrm{mg} / \mathrm{dl}$ で，L型においてやや上昇しており，とくに ENL では著しい高值を認めた。

5）総リポ蛋白の平均值も T型では $430 \mathrm{mg} / \mathrm{dl}$ と正常 值であったが, L型は $720 \mathrm{mg} / \mathrm{dl}$ と増加しており, ENL では $870 \mathrm{mg} / \mathrm{dl}$ と異常に増加していた。

6) すなわち，ENL では高中性脂肪血症を伴わない 高脂血症を示すことを証明できた。

7）なお，ENL の場合には血液凝固第一因子の fibrinogen 量も $430 \mathrm{mg} / \mathrm{dl}$ と著しく増加していた。

8）厶コ蛋白の平均值は $\mathrm{T}$ 型 $8.8 \mathrm{mg} / \mathrm{dl}, \mathrm{L}$ 型 $10 \mathrm{mg} / \mathrm{dl}$

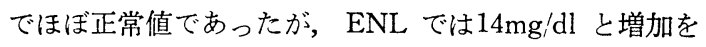
認めた。

\section{主要文献}

1) Balakrishnan, S. : Leprosy in India, $37: 247$ (1965).

2) de Brito, T., et al. : Intern. J. Leprosy, 37 : 154 (1969).

3) Dhople, A. M., and Magar, N. G. : Leprosy in India, $36: 87$ (1964).

4) Frederickson, D. S. : J. A. M. A., 164 : 1895 (1957).

5) 石戸谷豊, 伊藤忠一, 後藤恵子 : $\beta$-lipo set 文 献集 (1), ヤトロン社, 東京.

6) 石戸谷豊ほか 5 名 : 臨床病理, $18: 299$ (1970).

7) 真山 旭 : レプラ, $32: 199$ (1963) ; 長島紀要, No. 13, 1 (1965) ; レプラ, $36: 140$ (1967); $37: 41$ (1968).

8) Misra, U. K., and Venkitasubramanian, T. A. : Intern. J. Leprosy, 32 : 248 (1964).

9) Ross, Sister Hilary : Leprosy in India, 36 : 93, 193 (1964).

10) Shivde, A. V., and Junnarkar, R. V.: Intern. J. Leprosy, $35: 366$ (1967).

11）田中宏: (抄) レプラ, $32: 204$ (1963). 